\title{
THORACOLUMBAR BURST FRACTURE: STRUCTURAL CHANGES AND CLINICAL OUTCOME OF TREATMENT
}

\author{
FRATURA TORACOLOMBAR TIPO EXPLOSÃO: ALTERAÇÕES ESTRUTURAIS E \\ RESULTADO CLINICO DO TRATAMENTO
}

\author{
FRACTURA TORACOLUMBAR TIPO EXPLOSIÓN: CAMBIOS ESTRUCTURALES \\ Y RESULTADOS CLIINICO DEL TRATAMIENTO
}

\author{
Rodrigo Arnold Tisot ${ }^{1}, 2$, Juliano Silveira luiz Vieira ${ }^{2}$, Orley Fauth Tisot² ${ }^{2}$, Renato Tadeu dos Santos ${ }^{2}$, Augusto Alves Badotti², Andrius Berardi², \\ Diego da Silva Collares²
}

1. Faculdade de Medicina da Universidade de Passo Fundo, Passo Fundo, RS, Brasil.

2. Hospital Ortopédico de Passo Fundo, Grupo de Coluna, Passo Fundo, RS, Brasil.

\begin{abstract}
Objective: To evaluate the correlation between structural changes in burst fractures of thoracic and lumbar spine with clinical outcome of the treatment. Methods: A retrospective study in 25 patients with fractures of thoracic and lumbar spine burst fractures without neurological deficit. Eleven patients underwent conservative treatment and for the remaining the treatment was surgical. All patients were followed up for at least 24 months. The cases were evaluated by a protocol that included: posttraumatic measurement of kyphosis, vertebral body collapse and narrowing of the spinal canal, the visual analog scale of pain, and the quality of life questionnaire SF-36 at the follow-up. For statistical analysis, the significance level was 5\% and the software SPSS 18.0 was used. Results: No statistically significant difference was observed when comparing the clinical outcomes of one treatment over another. Similarly, there was no statistically significant correlation between kyphosis and post-traumatic narrowing of the spinal canal with clinical worsening in the follow-up, regardless of the treatment used. We found a positive correlation $(p<0.05)$ between initial collapse and SF-36 domains in both groups (operated and non-operated). Conclusion: There was no significant superiority of one treatment over the other, and no correlation was found between kyphosis and spinal canal narrowing in burst fractures of the thoracic and lumbar spine without neurological deficit. However, there was correlation between initial collapse and clinical outcome in some domains of the SF-36 questionnaire.
\end{abstract}

Keywords: Spinal injuries; Spinal fractures; Spine; Quality of life; Kyphosis; Spinal stenosis; Spinal canal.

\section{RESUMO}

Objetivo: Avaliar a correlação entre as alterações estruturais das fraturas da coluna torácica e lombar tipo explosão com o resultado clínico do tratamento. Métodos: Foi realizado estudo retrospectivo em 25 pacientes, com fraturas da coluna torácica ou lombar tipo explosão sem déficit neurológico. Onze pacientes foram submetidos ao tratamento conservador e, nos demais, o tratamento foi cirúrgico. Todos os pacientes foram acompanhados por, no mínimo, 24 meses. Os casos foram avaliados por um protocolo que incluiu: aferição pós-traumática da cifose, colapso do corpo vertebral e estreitamento do canal vertebral e escala visual analógica de dor e questionário de qualidade de vida SF-36 no seguimento. Para a análise estatística dos resultados foi considerado nível de significância de 5\% e utilizou-se o programa PASW 18.0. Resultados: Não foi evidenciada diferença estatisticamente significativa ao comparar os resultados clínicos de um tratamento sobre outro. Da mesma forma, não houve correlação estatisticamente significativa entre cifose e estreitamento pós-traumático do canal vertebral com piora clínica no seguimento, independentemente do tipo de tratamento adotado. Encontramos correlação positiva ( $p<0,05)$, entre colapso inicial e domínios do SF36 em ambos os grupos (operados e não operados). Conclusão: Não foi evidenciada superioridade de um tratamento sobre o outro, assim como não foi encontrada correlação entre cifose e estreitamento do canal vertebral nas fraturas da coluna torácica e lombar tipo explosão sem déficit neurológico. Porém, verificou-se correlação entre colapso inicial e desfecho clínico em alguns domínios do questionário SF36.

Descritores: Traumatismos da coluna vertebral; Fraturas da coluna vertebral; Coluna vertebral, Qualidade de vida; Cifose; Estenose espinal; Canal vertebral.

\section{RESUMEN}

Objetivo: Evaluar la correlación entre los cambios estructurales en las fracturas de la columna vertebral torácica y lumbar del tipo explosión con el resultado clínico del tratamiento. Métodos: Estudio retrospectivo de 25 pacientes con fracturas de la columna vertebral lumbar o torácica de tipo explosión y sin déficit neurológico. Once pacientes fueron sometidos a tratamiento consenvador y en los demás, el tratamiento fue quirúrgico. Todos los pacientes tuvieron seguimiento mínimo de 24 meses. Los casos fueron evaluados por un protocolo que incluyó: evaluación de la cifosis postraumática, colapso del cuerpo vertebral y el estrechamiento del canal espinal y la escala analógica visual de dolor y el cuestionario SF-36 durante el seguimiento. Para el análisis estadístico, se consideró el nivel de significación del 5\% y se utilizó el programa PASW 18.0. Resultados: No se obsenvaron diferencias estadísticamente significativas al comparar los resultados clínicos de un tratamiento sobre otro. También no hubo correlación estadísticamente significativa entre la cifosis y estrechamiento postraumático de canal espinal con empeoramiento clínico en el seguimiento, sin importar el tratamiento utilizado. Se encontró una correlación positiva $(p<0,05)$ entre el colapso inicial y dominios SF36 en ambos grupos (operados y no operados). Conclusión: No hubo superioridad significativa de un tratamiento sobre el otro y no se encontró correlación entre la cifosis y estrechamiento del canal espinal en las fracturas de la columna torácica o lumbar del tipo explosión sin déficit neurológico. Sin embargo, hubo correlación entre el colapso inicial y el resultado clínico en algunos dominios del cuestionario SF36.

Descriptores: Traumatismos vertebrales; Fracturas de la columna vertebral; Columna vertebral; Calidad de vida; Cifosis; Estenosis espinal; Conducto vertebral. 


\section{INTRODUCTION}

Burst fractures of the thoracic and lumbar spine usually occur in young individuals of working age. They are the result of high-energy axial compression, which generates anterior-posterior comminution of the entire vertebral body. As a result, retropulsion of bone fragments into the vertebral canal is evidenced. ${ }^{1}$

Various structural changes that occur in the fractured vertebra, such as kyphosis, collapse, and narrowing of the spinal canal, caused by fragments of the vertebral body, have been described in the literature as factors of great importance that interfere in the conduct to be adopted to treat these fractures. ${ }^{2}$ The location of the segment of spine in which the fracture occurs, and the presence of lamina fracture, can also interfere in the form of treatment to be carried out. ${ }^{3}$

Although various classifications have been proposed to assist the physician in defining the best therapeutic conduct, these fail to take into consideration the quantification of the abovementioned structural changes that affect the fractured vertebra.

Fractures with associated neurological deficit are indicated for surgery. ${ }^{4}$ However, most burst fractures of the thoracic and lumbar spine do not cause changes in neurological function. ${ }^{5}$ Therefore, no clear and precise definition is found in the literature, as regards the conduct to be adopted for these fractures, in which the patient presents normal neurological function (FRANKEL E). ${ }^{6.7}$ This lack of a clear definition partially explains why, to date, there is still no universally accepted treatment for this type of lesion. ${ }^{8.9}$

In view of the above, this study aims to evaluate the clinical results obtained in the follow-up of patients with burst fractures of the thoracic and lumbar spine type who underwent conservative or surgical treatment, taking into consideration the initial structural changes that occurred in the fractured vertebra.

\section{METHODS}

A retrospective study was conducted of 25 patients with burst fractures of the thoracic or lumbar spine, without associated neurological deficit, treated and in follow-up for at least 24 months, by the Spine Group of the Hospital Ortopédico de Passo Fundo (Passo Fundo Orthopedic Hospital) in the state of Rio Grande do Sul (RS). These patients were initially seen by the Emergency Departments of the Hospital do Cidade and Hospital São Vicente de Paulo, in Passo Fundo, RS. The clinical follow-up was conducted at Hospital Ortopédico, Passo Fundo - RS, in the period January 2002 to December 2011.

The authors of this study signed a Term of Commitment to maintain the confidentiality of the data used, and the study only began after the research project had received the approval of the Research Ethics Committee of the University of Passo Fundo (CEP/ UPF), under opinion number 242,895.

The classification used to define the fractures as burst-type was proposed by the $\mathrm{AO}$ Group. ${ }^{10}$

Of the 25 patients evaluated, 14 underwent surgical treatment (Group 1) and 11 cases underwent conservative treatment (Group 2). It should be emphasized that the previous criterion for adopting surgical treatment, in cases where neurological function was normal, was an angle of kyphosis of more than 30 degrees, collapse of the vertebral body of more than $50 \%$, or narrowing of the spinal canal of more than $50 \%$. Some patients with multiple trauma who underwent surgical treatment, but who did not fit the above criteria, were also surgically treated due to the need for early mobilization, seeking to minimize the risk of thromboembolic events and pulmonary infections. The patients who received surgical treatment were submitted to bone fusion with instrumentation in the vertebrae adjacent to the fracture, while those who received conservative treatment used a Jewett type spinal brace for a period of 16 to 24 months. (Table 1)

All cases had radiographs of the column in the anterior-posterior and profile views, a computed tomography, with axial, sagittal, and coronal sections (bone window). The scans were filed at the
Medical Records Department of the Hospital Ortopédico, Passo Fundo - RS. These images were evaluated in order to correctly classify the fractures. We also measured the angle of kyphosis, the percentage of collapse of the vertebral body, and percentage of spinal canal narrowing. ${ }^{11}$ (Table 2)

Table 1. Profile of the sample, with 25 patients evaluated.

\begin{tabular}{|c|c|c|c|c|c|c|c|c|}
\hline Patient & Sex & $\begin{array}{l}\text { Age: in } \\
\text { trauma }\end{array}$ & Treatment & $\begin{array}{c}\text { Follow-up } \\
\text { time } \\
\text { (months) }\end{array}$ & \begin{tabular}{|c|}
$\begin{array}{c}\text { Level } \\
\text { of the } \\
\text { fracture }\end{array}$ \\
\end{tabular} & ASIA & Etiology & $\begin{array}{l}\text { AO } \\
\text { Class }\end{array}$ \\
\hline 1 & $M$ & 50 & Surgical & 60 & T12 & $E$ & Fall & A3 \\
\hline 2 & $M$ & 34 & Surgical & 102 & L1 & $E$ & Direct trauma & A4 \\
\hline 3 & $M$ & 46 & Surgical & 108 & T8 & $E$ & Fall & $\mathrm{A} 3$ \\
\hline 4 & $M$ & 52 & Surgical & 51 & L1 & $E$ & Fall & A4 \\
\hline 5 & $M$ & 61 & Surgical & 75 & L1 & $E$ & Fall & A4 \\
\hline 6 & $M$ & 27 & Surgical & 68 & $\mathrm{~T} 12$ & $E$ & Fall & A3 \\
\hline 7 & $M$ & 39 & $\begin{array}{c}\text { Surgical } \\
\text { procedure }\end{array}$ & 52 & L3 & E & Fall & A3 \\
\hline 8 & $M$ & 49 & \begin{tabular}{|l|} 
Surgical \\
\end{tabular} & 31 & L2 & $E$ & Fall & A4 \\
\hline 9 & $M$ & 49 & Surgical & 52 & L1 & $E$ & Fall & A4 \\
\hline 10 & $\mathrm{~F}$ & 56 & Surgical & 96 & L2 & $E$ & Traffic Acc. & A4 \\
\hline 11 & $M$ & 41 & Surgical & 65 & L2 & $E$ & Fall & A4 \\
\hline 12 & $M$ & 69 & Surgical & 76 & $\mathrm{~L} 1$ & $E$ & Fall & $\mathrm{A} 3$ \\
\hline 13 & $M$ & 61 & Surgical & 96 & L3 & $E$ & Fall & A4 \\
\hline 14 & $M$ & 36 & Surgical & 89 & L1 & $E$ & Fall & A4 \\
\hline 15 & $\mathrm{M}$ & 22 & Clinical & 86 & T5 & $E$ & Traffic Acc. & A3 \\
\hline 16 & $M$ & 37 & Clinical & 71 & $\mathrm{~L} 2$ & $E$ & Traffic Acc. & $\mathrm{A} 3$ \\
\hline 17 & $M$ & 47 & Clinical & 33 & L3 & $E$ & Fall & $A 3$ \\
\hline 18 & $\mathrm{~F}$ & 24 & Clinical & 39 & T12 & $E$ & Traffic Acc. & $\mathrm{A} 3$ \\
\hline 19 & $M$ & 48 & Clinical & 26 & $\mathrm{~L} 1$ & $\mathrm{E}$ & Traffic Acc. & A4 \\
\hline 20 & $\mathrm{~F}$ & 54 & Clinical & 27 & L1 & $E$ & Fall & A3 \\
\hline 21 & $M$ & 61 & Clinical & 26 & $\mathrm{~T} 12$ & $E$ & Fall & A4 \\
\hline 22 & $\mathrm{~F}$ & 36 & Clinical & 33 & $\mathrm{~L} 1$ & $E$ & Fall & $\mathrm{A} 3$ \\
\hline 23 & $\mathrm{M}$ & 40 & Clinical & 48 & L2 & $E$ & Direct trauma & $\mathrm{A} 3$ \\
\hline 24 & $\mathrm{~F}$ & 62 & Clinical & 64 & L2 & $E$ & Fall & $\mathrm{A} 3$ \\
\hline 25 & $M$ & 56 & Clinical & 24 & L2 & $E$ & Fall & A4 \\
\hline
\end{tabular}

Source: Medical files of the Hospital Ortopédico de Passo Fundo, RS.

Table 2. Acute structural changes in the fractured vertebrae.

\begin{tabular}{c|c|c|c}
\hline Patient & $\begin{array}{c}\text { Initial local kyphosis } \\
\text { (Degrees) }\end{array}$ & $\begin{array}{c}\text { Initial collapse of the } \\
\text { vertebral body (\%) }\end{array}$ & $\begin{array}{c}\text { Retropulsion to the } \\
\text { vertebral canal (\%) }\end{array}$ \\
\hline 1 & 34 & 35.0 & 30.0 \\
\hline 2 & 16 & 43.9 & 42.0 \\
\hline 3 & 35 & 66.7 & 15.0 \\
\hline 4 & 2 & 32.3 & 35.0 \\
\hline 5 & 13 & 55.2 & 67.0 \\
\hline 6 & 26 & 46.7 & 20.0 \\
\hline 7 & -4 & 5.1 & 70.0 \\
\hline 8 & 12 & 40.5 & 64.0 \\
\hline 9 & 30 & 60.0 & 60.0 \\
\hline 10 & 3 & 53.1 & 50.0 \\
\hline 11 & 25 & 40.0 & 55.0 \\
\hline 12 & 4 & 50.0 & 27.0 \\
\hline 13 & 0 & 56.9 & 45.0 \\
\hline 14 & 10 & 54.9 & 45.0 \\
\hline 15 & 24 & 40.0 & 10.0 \\
\hline 16 & 12 & 31.2 & 35.0 \\
\hline 17 & -10 & 31.4 & 20.0 \\
\hline 18 & 23 & 21.9 & 10.0 \\
\hline 19 & 13 & 36.8 & 42.0 \\
\hline 20 & 9 & 20.0 & 20.0 \\
\hline 21 & 14 & 25.3 & 35.0 \\
\hline 22 & 3 & 15.9 & 12.0 \\
\hline 23 & 4 & 21.7 & 20.0 \\
\hline 24 & 6 & 13.8 & 15.0 \\
\hline 25 & 4 & 22.0 & 25.0 \\
\hline
\end{tabular}

Source: Medical files of the Hospital Ortopédico de Passo Fundo,RS. 
All patients were evaluated during a minimum 24-month follow-up, using the visual analogue scale (VAS) and the quality of life questionnaire Short Form-36 ${ }^{12}$ (SF-36). (Table 3)

For the statistical analysis of this study, a level of significance of $0.05(\alpha=5 \%)$ was used, and descriptive levels $(p)$ lower than this value were considered significant and represented by $p<0.05$. The Mann-Whitney test and Spearman's correlation analysis were also applied. The PASW program, version 18.0, was used for the analysis and to obtain the results.

\section{RESULTS}

The results were obtained for: (a) demographic data; (b) relationship between treatment received and clinical outcome; (c) relationship between initial angle of kyphosis and clinical outcome; (d) relationship between initial collapse of the vertebral body and clinical outcome, and (e) relationship between initial narrowing of the vertebral canal and clinical outcome.

\section{Demographic data}

Twenty of the patients were male (80\%) and 5 were female (20\%). In relation to the etiology of the trauma responsible for the fracture, it was found that falling from a height was the cause in 18 cases (72\%), traffic accidents in five cases (20\%) and direct trauma in only two cases $(8 \%)$

Table 3. The visual analogue scale (VAS) and domains of the SF-36 questionnaire in the minimum two-year follow-up.

\begin{tabular}{|c|c|c|c|c|c|c|c|c|c|}
\hline Patient & VAS & $\begin{array}{c}\text { Functio- } \\
\text { nal } \\
\text { Cap. }\end{array}$ & $\begin{array}{c}\text { Lim. } \\
\text { due to } \\
\text { physical } \\
\text { aspects }\end{array}$ & Pain & $\begin{array}{c}\text { EGS } \\
*\end{array}$ & Vitality & $\begin{array}{c}\text { Social } \\
\text { aspects }\end{array}$ & $\begin{array}{c}\text { Lim. due to } \\
\text { emotional } \\
\text { aspects }\end{array}$ & $\begin{array}{l}\text { Mental } \\
\text { health }\end{array}$ \\
\hline 1 & 8 & 70 & 25 & 52 & 42 & 50 & 50 & 33 & 48 \\
\hline 2 & 6 & 55 & 0 & 30 & 57 & 60 & 63 & 0 & 56 \\
\hline 3 & 4 & 95 & 25 & 74 & 67 & 70 & 38 & 100 & 52 \\
\hline 4 & 7 & 30 & 0 & 32 & 52 & 45 & 75 & 0 & 60 \\
\hline 5 & 5 & 60 & 25 & 10 & 67 & 50 & 50 & 33 & 36 \\
\hline 6 & 6 & 15 & 0 & 32 & 57 & 50 & 38 & 33 & 56 \\
\hline 7 & 3 & 30 & 0 & 52 & 77 & 55 & 63 & 0 & 64 \\
\hline 8 & 7 & 10 & 0 & 10 & 42 & 75 & 38 & 0 & 36 \\
\hline 9 & 3 & 100 & 25 & 74 & 62 & 75 & 50 & 100 & 52 \\
\hline 10 & 9 & 45 & 0 & 10 & 70 & 35 & 50 & 0 & 48 \\
\hline 11 & 10 & 0 & 0 & 0 & 80 & 50 & 63 & 0 & 32 \\
\hline 12 & 0 & 20 & 75 & 10 & 77 & 60 & 25 & 100 & 60 \\
\hline 13 & 5 & 60 & 100 & 52 & 62 & 65 & 63 & 100 & 60 \\
\hline 14 & 4 & 60 & 50 & 10 & 52 & 60 & 50 & 100 & 48 \\
\hline 15 & 7 & 65 & 0 & 74 & 80 & 55 & 88 & 0 & 56 \\
\hline 16 & 9 & 70 & 0 & 30 & 62 & 55 & 75 & 0 & 48 \\
\hline 17 & 4 & 85 & 100 & 84 & 52 & 50 & 50 & 67 & 64 \\
\hline 18 & 4 & 85 & 25 & 62 & 67 & 60 & 50 & 67 & 56 \\
\hline 19 & 4 & 45 & 25 & 74 & 72 & 55 & 38 & 0 & 52 \\
\hline 20 & 8 & 35 & 0 & 10 & 77 & 45 & 50 & 0 & 40 \\
\hline 21 & 8 & 25 & 25 & 10 & 67 & 65 & 50 & 0 & 52 \\
\hline 22 & 9 & 55 & 25 & 10 & 72 & 50 & 63 & 0 & 48 \\
\hline 23 & 4 & 55 & 100 & 62 & 57 & 60 & 63 & 67 & 56 \\
\hline 24 & 5 & 20 & 0 & 10 & 57 & 25 & 25 & 0 & 48 \\
\hline 25 & 1 & 65 & 0 & 74 & 77 & 55 & 50 & 0 & 56 \\
\hline
\end{tabular}

Source: Medical files of the Hospital Ortopédico de Passo Fundo, RS. *general health status
In regard to the spine segment affected, the majority of cases occurred in the thoracolumbar transition (T12-L1), with 13 cases (52\%). There were 10 (40\%) cases in the lumbar region (L2 to L5), and only two cases (8\%) in the thoracic region (T1 to T11).

In terms of recommended treatment, of the 25 patients studied, 14 (56\%) were treated surgically and 11 (44\%) were treated conservatively. The median age at the time of trauma (percentile 50) was 49 years for the surgically treated patients and 47 years for the patients treated conservatively.

Analysis of the fractures by the AO classification showed that of the operated patients, $35.7 \%$ of the cases were type $\mathrm{A} 3$ and $64.3 \%$ were type A4. In the patients treated conservatively, $72.7 \%$ of the injuries were type $\mathrm{A} 3$ and $27.3 \%$ were type $\mathrm{A} 4$.

\section{Relationship between treatment received and clinical outcome.}

Based on the evaluation method used, no statistically significant difference $(p<0.05)$ was found, in the comparison of clinical results (VAS and Domains of the SF36) obtained in the minimum 24-month follow-up, between the surgically treated patients and those treated conservatively. (Table 4)

\section{Relationship between initial kyphosis and clinical outcome}

No statistically significant correlation $(p<0.05)$ was found between the initial and VAS kyphosis or domains of the SF-36, both in patients conservatively and in those treated surgically. (Table 5)

\section{Relationship between collapse of the vertebral body and clinical outcome.}

There was no statistically significant correlation $(p<0.05)$ between initial collapse of the vertebral body and VAS, whether in the patients treated conservatively or those treated surgically.

In patients treated surgically, the correlation between collapse and SF-36 questionnaire was statistically significant only for the domains functional capacity $(p=0.022)$, limitations due to physical aspects $(p=0.019)$, and limitations due to emotional aspects $(p=0.002)$. In the patients treated conservatively, the correlation between vertebral collapse and the SF-36 questionnaire was statistically significant only for the domain pain $(p=0.012)$. (Table 5)

\section{Relationship between vertebral canal narrowing and clinical outcome}

There was no statistically significant correlation $(p<0.05)$ between vertebral canal narrowing and VAS or the domains of the SF-36, either in the patients treated conservatively or in those treated surgically. (Table 5)

\section{DISCUSSION}

The treatment of burst fractures of the thoracolumbar spine is a topic of debate and discussion in the literature. The majority of

Table 4. Relationship between VAS and the SF-36 Domains, and the treatment carried out.

\begin{tabular}{c|c|c|c}
\hline Variable & \multicolumn{2}{|c|}{ Median } & \multirow{2}{*}{ * $^{*}$} \\
\cline { 1 - 2 } Domains of SF36 & Surgical & $\begin{array}{c}\text { Conserva- } \\
\text { tive }\end{array}$ & \\
\hline Functional capacity & 50.0 & 55.0 & 0.395 \\
\hline Limitation due to physical aspects & 12.5 & 25 & 0.836 \\
\hline Pain & 31 & 62 & 0.248 \\
\hline Overall health status & 62 & 67 & 0.258 \\
\hline Vitality & 57.5 & 55 & 0.436 \\
\hline Social aspects & 50 & 50 & 0.648 \\
\hline Limitation due to emotional aspects & 33.33 & 0 & 0.115 \\
\hline Mental health & 52 & 52 & 0.867 \\
\hline VAS & 5.5 & 5 & 0.83 \\
\hline
\end{tabular}

\footnotetext{
${ }^{* *}$ The correlation is significant when $p<0.05$
} 
Table 5. Relationship between structural changes of the fractured vertebra, and VAS and SF-36 Domains

\begin{tabular}{|c|c|c|c|c|c|c|c|}
\hline \multicolumn{2}{|c|}{ Variables } & \multicolumn{2}{|c|}{ Initial kyphosis } & \multicolumn{2}{|c|}{ Initial collapse } & \multicolumn{2}{|c|}{$\begin{array}{l}\text { Narrowing } \\
\text { of the canal }\end{array}$} \\
\hline $\begin{array}{c}\text { SF36 } \\
\text { domains }\end{array}$ & Treatment & $\begin{array}{l}\text { Spearman's } \\
\text { correlation }\end{array}$ & $P^{*}$ & $\begin{array}{l}\text { Spearman's } \\
\text { Correlation }\end{array}$ & $P^{*}$ & $\begin{array}{c}\text { Spearman's } \\
\text { Correlation }\end{array}$ & $P^{*}$ \\
\hline \multirow{2}{*}{$\begin{array}{c}\text { Functional } \\
\text { capacity }\end{array}$} & Surgical & 0.343 & 0.231 & 0.606 & 0.022 & -0.111 & 0.707 \\
\hline & Conservative & -0.050 & 0.883 & 0.435 & 0.181 & -0.241 & 0.475 \\
\hline \multirow{2}{*}{$\begin{array}{l}\text { Limitation } \\
\text { due to physi- } \\
\text { cal aspects }\end{array}$} & Surgical & 0.019 & 0.949 & 0.618 & 0.019 & -0.219 & 0.452 \\
\hline & Conservative & -0.332 & 0.319 & 0.074 & 0.830 & 0.045 & 0.896 \\
\hline \multirow{2}{*}{ Pain } & Surgical & 0.233 & 0.422 & 0.215 & 0.460 & -0.252 & 0.386 \\
\hline & Conservative & -0.045 & 0.896 & 0.725 & 0.012 & 0.067 & 0.845 \\
\hline \multirow{2}{*}{$\begin{array}{c}\text { Overall } \\
\text { health status }\end{array}$} & Surgical & -0.190 & 0.515 & 0.135 & 0.646 & 0.210 & 0.470 \\
\hline & Conservative & 0.414 & 0.206 & 0.183 & 0.589 & -0.112 & 0.744 \\
\hline \multirow{2}{*}{ Vitality } & Surgical & 0.201 & 0.490 & 0.465 & 0.094 & 0.060 & 0.837 \\
\hline & Conservative & 0.473 & 0.142 & 0.369 & 0.264 & 0.211 & 0.534 \\
\hline \multirow{2}{*}{$\begin{array}{c}\text { Social } \\
\text { aspects }\end{array}$} & Surgical & -0.414 & 0.142 & -0.398 & 0.159 & 0.335 & 0.242 \\
\hline & Conservative & 0.098 & 0.774 & 0.258 & 0.444 & -0.262 & 0.437 \\
\hline \multirow{2}{*}{$\begin{array}{l}\text { Limitation } \\
\text { due to } \\
\text { emotional } \\
\text { aspects }\end{array}$} & Surgical & 0.261 & 0.366 & 0.749 & 0.002 & -0.375 & 0.186 \\
\hline & Conservative & -0.226 & 0.503 & 0.000 & 1.000 & -0.295 & 0.379 \\
\hline \multirow{2}{*}{$\begin{array}{l}\text { Mental } \\
\text { health }\end{array}$} & Surgical & -0.472 & 0.089 & -0.131 & 0.655 & -0.287 & 0.319 \\
\hline & Conservative & -0.052 & 0.880 & 0.504 & 0.114 & -0.165 & 0.628 \\
\hline \multirow{2}{*}{ VAS } & Surgical & 0.124 & 0.673 & -0.415 & 0.140 & 0.004 & 0.988 \\
\hline & Conservative & 0.143 & 0.675 & -0.178 & 0.601 & -0.450 & 0.9 \\
\hline
\end{tabular}

*The correlation is significant when $p<0.05$. In bold, evidenced statistically significant values.

patients with this type of fracture do not present neurological deficit or direct criteria of instability, making it difficult to define the therapeutic conduct. ${ }^{13-15}$ In general, surgical treatment is proposed for patients with associated neurological damage. ${ }^{16}$ However, doubt remains as to the best conduct to be adopted when the patient presents normal neurological function. Should we classify this type of fracture as unstable, in order to justify a surgical indication? We must remember that bone instability alone, after acute trauma, ceases to exist after consolidation of the fracture. The severity of burst fracture without associated neurological deficit could be expressed by comminution of the fractured vertebral body, the presence of lamina fracture, increased kyphosis, and collapse, and narrowing of the spinal canal due to bone fragments from the fracture. ${ }^{17}$ But is the presence or extent of the factors mentioned above related to the final outcome of the treatment?

Observational studies in patients with burst fractures of the thoracic and lumbar spine and normal neurological function have not shown any differences in the functional results in the long term, independently of whether they received surgical or conservative treatment. ${ }^{18-20}$ The authors that defend surgical treatment do so based on the good results obtained, shorter hospitalization times, early mobility, better correction of kyphosis, and the possibility of direct decompression of the vertebral canal, which would prevent possible subsequent neurological deterioration. ${ }^{21-24}$

In a prospective, randomized study, Wood et al., ${ }^{25}$ compared the results of surgical treatment and conservative treatment in 47 patients with thoracolumbar burst fractures (24 treated surgically and 23 with a brace or plaster cast). Radiographic analysis showed similar results in relation to the kyphosis (mean of $10.1^{\circ}$ on admission and residual of $13^{\circ}$ ), narrowing of the spinal canal (mean of $39 \%$ on admission and residual of 22\%), in both operated and non-operated patients. The final scores in the SF-36 and Oswestry questionnaires were similar for both groups, although there was a certain trend in favor those treated conservatively. Complications were more frequent in the group treated surgically. In another study of the meta-analysis type, Sonali et al., ${ }^{26}$ assessed four clinical trials on the treatment of thoracolumbar burst fractures, with a total of 79 patients (41 with surgical treatment and 38 with conservative treatment). The mean follow-up ranged from 24 to 118 months. Differences were found between the groups in terms of the improvement in kyphosis in the group treated with surgery. However, the surgical treatment did not show any superiority in relation to pain or the rate of return to work. They therefore concluded that surgical treatment of thoracolumbar burst fractures without neurological deficit can improve the residual kyphosis, but does not improve the pain, and is associated with higher rates of complications and costs. Yi et al., ${ }^{27}$ in another meta-analysis, found similar results. Avanzi et al., ${ }^{28}$ in a retrospective analysis, also evaluated the correlation between narrowing of the vertebral canal and clinical outcome in patients with thoracolumbar burst fractures without neurological deficit who underwent conservative treatment only. In their review of the SF-36, they also found no correlation between narrowing of the vertebral canal narrowing poorer clinical outcomes. Also in relation to narrowing of the vertebral canal, Munford et al. ${ }^{29}$ And De Klerk et al., ${ }^{30}$ observed, in their work on thoracolumbar burst fractures of the spine without associated neurological deficit, remodeling of the spinal canal in the medium and long terms, in patients submitted to conservative treatment. This fact is what leads us to question the possible late neurological deterioration, when surgical decompression of vertebral canal is performed in cases of significant narrowing of the canal. In our study, we also did not find a statistically significant correlation between initial kyphosis and narrowing of the vertebral canal, and clinical outcome, both in patients treated surgically and those treated conservatively, even though our sample selected cases with generally greater kyphosis and narrowing of the vertebral canal, to undergo surgery.

This study also evaluated the relationship between vertebral collapse and clinical outcome obtained in the follow-up (VAS and SF-36), both in patients treated conservatively and in those treated surgically. A positive correlation was found in the group that underwent surgery, in some areas of the SF-36 (functional capacity, limitation due to physical aspects, and limitation due to emotional aspects) and, in the group treated conservatively, in the domain pain. In these areas, we found values of $p<0.05$ and a positive Spearman's coefficient of correlation, i.e. patients with a higher percentage of initial collapse presented better clinical outcomes in some domains of the SF-36. Our hypothesis for this apparently paradoxical result is that patients with higher values for initial collapse benefit from surgical treatment, perhaps because it minimizes the effects of possible discopathies caused by the high-energy axial trauma, lesions that are difficult to diagnose on admission. However, there was no similar outcome when correlating VAS and collapse of the vertebral body. (Table 5) There is a lack of studies, in the current literature, evaluating collapse of the vertebral body and its correlation with the clinical outcome.

Therefore, although our results are consistent with the literature, in the majority of the findings, the fact that we found a weak correlation between collapse of the vertebral body and clinical outcome indicates a need for further studies correlating vertebral collapse are needed, in order to clarify the factors related to the collapse (such as disc and interfacet injuries), which could influence the clinical results obtained in the follow-up.

With respect to the standardization of treatment conduct for this type of lesion, we suggest that more prospective studies be conducted, with bigger samples, and with a selection protocol that allows the inclusion of patients with injuries that are more alike. Until that happens, the concerns of the spine surgeon faced with this problem will remain, requiring good sense and individualized treatment for each case, when indicating treatment.

\section{CONCLUSION}

Regardless of the type of treatment adopted, patients with burst fractures of the thoracic or lumbar spine without associated neurological deficit presented similar clinical results in the follow-up, in both the SF36 and VAS questionnaires. 
Neither were any significant correlations with clinical outcome found in relation to acute kyphosis and narrowing of the vertebral canal.

Initial collapse of vertebral body showed a statistically significant correlation with clinical outcome in only some domains of the SF36. The same correlation was not evidenced with the VAS. We note that there is a need for more studies, with a larger number of cases, to determine the real influence of initial vertebral collapse on clinical outcome, regardless of the treatment indicated.

\section{ACKNOWLEDGMENTS}

We are grateful for the technical support of Universidade de Passo Fundo, RS; Hospital Ortopédico de Passo Fundo, RS; Hospital da Cidade de Passo Fundo, RS and Hospital São Vicente de Paulo de Passo Fundo, RS.

All authors declare no potential conflict of interest concerning this article.

CONTRIBUTIONS OF AUTHORS: Each author contributed individually and significantly to the development of the manuscript. RAT was the main author responsible for defining the research to be conducted, and also made corrections to the text. AB and DSC gathered the data and wrote the initial dissertation of the text. JSLV, OFT and RTS granted patients for the study and assisted in correcting the text.

\section{REFERENCES}

1. Holdsworth F. Fractures, dislocations, and fracture-dislocations of the spine. J Bone Joint Surg Am. 1970;52(8):1534-51.

2. Denis F. The three column spine and its significance in the classification of acute thoracolumbar spinal injuries. Spine (Phila Pa 1976). 1983;8(8):817-31.

3. McAfee PC, Yuan HA, Lasda NA. The unstable burst fracture. Spine (Phila PA 1976). 1982:7(4):365-73.

4. Vaccaro AR, Lehman RA Jr, Hurlbert RJ, Anderson PA, Harris M, Hedlund R, et al. A new classification of thoracolumbar injuries: the importance of injury morphology, the integrity of the posterior ligamentous complex, and neurologic status. Spine (Phila Pa 1976). 2005;30(20):2325-33

5. HaherTR, Bergman M, O'Brien M, Felmly WT, Choueka J, Welin D, et al. The effect of the three columns of the spine on the instantaneous axis of rotation in flexion and extension. Spine (Phila Pa 1976). 1991;(8 Suppl):S312-8.

6. Frankel HC, Hancocck DO, Hyslop G. The value of postural reduction in the initial management of closed injuries of the spine with paraplegia and tetraplegia. Paraplegia. 1969;7:179-92.

7. Gennari TD, Koizumi MS. Determination of the trauma severity level. Rev Saude Publica. 1995; 29(5):333-41.

8. Whitesides TE Jr. Traumatic kyphosis of the thoracolumbar spine. Clin Orthop Relat Res. 1977;(128):78-92.

9. Long WB, Bachulis BL, Hynes GD. Accuracy and relationship of mechanisms of injury, trauma score, and injury severity score in identifying major trauma. Am J Surg. 1986:151(5):581-4.

10. Vaccaro AR, Oner C, Kepler CK, Dvorak M, Schnake K, Bellabarba C, et al. AOSpine thoracolumbar spine injury classification system: fracture description, neurological status, and key modifiers. Spine (Phila Pa 1976). 2013:38(23):2028-37.

11. Knight RQ, Stornelli DP, Chan DP, Devanny JR, Jackson KV. Comparison of operative versus nonoperative treatment of lumbar burst fractures. Clin Orthop Relat Res. 1993;(293):112-21.

12. Ware JE Jr, Sherbourne CD. The MOS 36-item short-form health survey (SF-36). Conceptual framework and item selection. Med Care. 1992;30(6):473-83.

13. Tisot RA, Avanzi O. Fratura da coluna vertebral tipo explosão na área da cauda eqüina: correlação entre função neurológica e alterações estruturais no canal vertebral. Acta Ortop Bras. 2008;16(2):85-8.

14. Chow GH, Nelson BJ, Gebhard JS, Brugman JL, Brown CW, Donaldson DH. Functional outcome of thoracolumbar burst fractures managed with hyperextension casting or bracing and early mobilization. Spine (Phila Pa 1976). 1996;21(18):2170-5.

15. Defino HLA, Fuentes ARR, Remondi PH, Ballim EC. Tratamento conservador das fraturas da coluna toracolombar. Rev Bras Ortop. 2000;35(8):301-8.
16. Vaccaro AR, Kim DH, Brodke DS, Harris M, Chapman JR, Schildhauer T, et al. Diagnosis and management of thoracolumbar spine fractures. Instr Course Lect. 2004:53:359-73.

17. Cammisa FP Jr, Eismont FJ, Green BA. Dural laceration occurring with burst fractures and associated laminar fractures. J Bone Joint Surg Am. 1989;71(7):1044-52.

18. Denis F, Armstrong GW, Searls K, Matta L. Acute thoracolumbar burst fractures in the absence of neurologic deficit. A comparison between operative and nonoperative treatment. Clin Orthop Relat Res. 1984;(189):142-9.

19. Kraemer WJ, Schemitsch EH, Lever J, McBroom RJ, McKee MD, Waddell JP. Functional outcome of thoracolumbar burst fractures without neurological deficit. J Orthop Trauma. 1996;10(8):541-4.

20. Avanzi O, Chih LY, Neves R, Caffaro MFS, Bueno RS, Freitas MMF. Fratura toracolombar tipo explosão: resultados do tratamento conservador. Rev Bras Ortop. 2006;41(4):109-15.

21. Bradford DS, Akbarnia BA, Winter RB, Seljeskog EL. Surgical stabilization of fractures and fracture-dislocations of the thoracic spine. Spine. 1977;2(2):185-96.

22. Sanderson PL, Fraser RD, Hall DJ, Cain CM, Osti OL, Potter GR. Short segment fixation of thoracolumbar burst fractures without fusion. Eur Spine J. 1999;8(6):495-500.

23. Andress HJ, Braun $H$, Helmberger T, Schürmann M, Hertlein $H$, Hartl WH. Long-term results after posterior fixation of thoraco-lumbar burst fractures. Injury. 2002;33(4):357-65.

24. Aebi M, Etter $C$, Kehl T, Thalgott J. Stabilization of the lower thoracic and lumbar spine with the internal spinal skeletal fixation system. Indications, techniques, and first results of treatment. Spine (Phila Pa 1976). 1987;12(6):544-51.

25. Wood K, Buttermann G, Mehbod A, Garvey T, Jhanjee R, Sechriest V. Operative compared with nonoperative treatment of a thoracolumbar burst fracture without neurological deficit. A prospective, randomized study. J Bone Joint Surg Am. 2003;85-A(5):773-81.

26. Gnanenthiran SR, Adie S, Harris IA. Nonoperative versus operative treatment for thoracolumbar burst fractures without neurologic deficit: a meta-analysis. Clin Orthop Relat Res. 2012;470(2):567-77.

27. Yi L, Jingping B, Gele J, Baoleri X, Taixiang W. Operative versus non-operative treatment for thoracolumbar burst fractures without neurological deficit. Cochrane Database Syst Rev. 2006; (4):CD005079.

28. Avanzi O, Meves R, Caffaro MFS, Caffaro MFS, Santos DF. Correlação entre a abertura interpedicular e o comprometimento do canal vertebral na fratura toracolombar em explosão. Coluna/Columna. 2008:7(4):361-6.

29. Mumford J, Weinstein JN, Spratt KF, Goel VK. Thoracolumbar burst fractures. The clinical efficacy and outcome of nonoperative management. Spine (Phila PA 1976) 1993;18(8):955-70

30. de Klerk LW, Fontijne WP, Stijnen T, Braakman R, Tanghe HL, van Linge B. Spontaneous remodeling of the spinal canal after conservative management of thoracolumbar burst fractures. Spine (Phila Pa 1976). 1998;23(9):1057-60 